\title{
Experimental Studies on the Passage of Non- pathogenic Bacteria through the Kidney
}

\author{
By
}

\author{
Masakazu Saheki \\ (佐 伯 正 $\rightarrow$ ) \\ From the Prof. M. Muto's Surgical Clinic, Tohoku \\ University, Sendai
}

(Received for publication, April 16, 1954)

The question whether bacteria pass through the normal kidney has long been a matter of interests to a great number of investigators, but still remains unsettled even now. Though not a few earlier workers seem to have used experimental methods in which some defects may be pointed out at present, Helmholz and Millikin, ${ }^{11}$ Tschiknawerow, ${ }^{2)}$ Book $^{3)}$ and others carried out precise experiments, which led them to deny the view that bacteria can pass through the normal kidney. In our country, however there have often been published reports in favor of this view of passage even quite recently (Tsutsui, ${ }^{4)}$ Nishikawas, ${ }^{5}$ Orikasa, ${ }^{61}$ Okubo, ${ }^{7)}$ Abe, ${ }^{81}$ and others). As the solution of this question is necessary also from a clinical standpoint, I attempted experiments with non-pathogenic bacteria, in parallel with those using pathogenic bacteria by Mr. K. Monma ${ }^{9)}$ in our clinic, with the results to deny the passage of bacteria through the kidney and also to explain the reason for the discrepancy of results reported in the literature, as will be described in the present paper.

\section{EXPERIMENTAL}

\section{Material and Methods}

A total of 42 healthy adult rabbits weighing about $2 \mathrm{~kg}$. were used. Bacteria were injected into the ear veins. Samples of the urine were taken for culture $0.5,1,2,3,4,3,6$, and 7 hours after the injection, based upon a common medical knowledge that the excretion by the kidney of foreign bodies in the circulation is at its maximum 0.5 to 1 hour after their introduction into the blood stream.

Bacterial suspension for injection. The species of bacteria used were those of well growing non-pathogenic ones, such as $B$. subtilis (PCI-219), an enterococcus (isolated from normal feces), $B$. proteus vulgaris $\left(\mathrm{OX}_{19}\right)$, avirulent $B$. coli (divided from the strain kept in the Department of Bacteriology 
of our university), and an avirulent acid-fast bacillus Mycobacterium 607. For intravenous injection, $5 \mathrm{cc}$. of $24-\mathrm{hr}$. broth culture was used in the cases of non-acid-fast bacteria, and $10 \mathrm{mg}$. of Lockemann's medium culture, suspended in physiological saline solution, was used in the case of Mycobacterium 607.

Taking urine samples. In the present investigation, scrupulous care should be taken not to mix blood in collecting the urine. For this, the rabbit was fixed on a bench in dorsal position, the lower abdomen shaved, laparotomy by the lower midline incision performed in anesthetized and sterilized condition, the whole bladder turned out of the incision, and its surroundings covered with a sterile cloth. About $5 \mathrm{cc}$. of the urine sample was obtained by plunging quickly an $1 / 3 \mathrm{~mm}$.-needle and syringe into the bladder through a place of the bladder wall where no relatively large blood vessel was present.

Test for bacteria in the urine. Non-acid-fast bacteria were tested for by culture on an ordinary agar plate directly or after having been enriched in broth, and acid-fast bacilli by microscopic examination of the stained sediments of the urine or by culture. For culture, Oka-Katakura's medium was used. The determination of presence or absence of bacteria was made by inspecting 6 tubes for a given sample cultured for 3 months.

Test for bacteria in the blood. A sample of blood was obtained from an ear vein or the femoral vein once before injection of bacterial suspension and at each time of taking the urine (9 samples in all). Non-acid-fast bacteria were tested for by incubating a drop of blood in broth, and acidfast bacilli by incubating about 2 cc. of blood.

Tests for erythrocytes and albumin in the urine. When a sample of urine was to be obtained, special care was taken in testing for erythrocytes by microscopic examination of the urinary sediments or by the benzidine test. For albumin, the sulfosalicylic acid test was made.

\section{Results}

Series 1: Experiments with B. subtilis. In each of 6 of 8 rabbits tested, the 8 samples of the bladder urine taken after injection were constantly negative for bacteria both on plate and in broth; they all contained no erythrocytes, and gave negative benzidine test (Table I).

In the remaining 2 cases, on the other hand, the urine was constantly positive in broth in the 1-hr. and later samples, and positive even on plate in the 4- or 6-hr. sample. So far as the results of culture on plate are concerned, the urine had remained negative for bacteria till 3 hours after injection. The positive urine samples contained erythrocytes, increased numbers of erythrocytes being detected in the samples positive for bacteria 
TABLE I

Changes by Injection of B. subtilis

\begin{tabular}{|c|c|c|c|c|c|c|c|c|c|c|c|}
\hline \multirow{2}{*}{ No. } & & & \multirow{2}{*}{$\begin{array}{l}\text { Before } \\
\text { injection }\end{array}$} & \multicolumn{8}{|c|}{ Time (hrs.) after injection } \\
\hline & & & & 0.5 & 1 & 2 & 3 & 4 & 5 & 6 & 7 \\
\hline \multirow{5}{*}{19} & \multirow{2}{*}{ 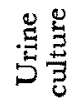 } & in broth & - & - & - & - & - & - & - & - & - \\
\hline & & on plate & - & - & - & - & - & - & - & - & - \\
\hline & \multicolumn{2}{|c|}{ Erythrocytes in urine } & - & - & - & - & - & - & - & - & - \\
\hline & \multicolumn{2}{|c|}{ Benzidine test } & - & - & - & - & - & - & - & - & - \\
\hline & \multicolumn{2}{|c|}{ Albumine in urine } & - & - & - & - & - & - & - & - & - \\
\hline
\end{tabular}

on plate. The bacterium-positive samples were also positive for the benzidine test, but negative for albumin (Table II).

T A B LE II

Changes by Injection of $\mathrm{B}$. subtilis

\begin{tabular}{|c|c|c|c|c|c|c|c|c|c|c|c|}
\hline \multirow{2}{*}{ No. } & & & \multirow{2}{*}{$\begin{array}{l}\text { Before } \\
\text { injection }\end{array}$} & \multicolumn{8}{|c|}{ Time (hrs.) after injection } \\
\hline & & & & 0.5 & 1 & 2 & 3 & 4 & 5 & 6 & 7 \\
\hline \multirow{5}{*}{17} & \multirow{2}{*}{ 导总 } & in broth & - & - & + & + & + & + & + & + & + \\
\hline & & on plate & - & - & - & - & - & - & - & + & + \\
\hline & \multicolumn{2}{|c|}{ Erythrocytes* in urine } & - & - & + & H & H & H & H & H & \# \\
\hline & \multicolumn{2}{|c|}{ Benzidine test } & - & - & - & + & + & + & + & + & + \\
\hline & \multicolumn{2}{|c|}{ Albumin in urine } & - & - & - & - & - & - & - & - & - \\
\hline
\end{tabular}

* Erythrocytes; \pm Doutful. + Less than one cell in several visual fields. H Less than several cells in one visual field. \# More than several cells in one visual field.

As for bacteria in the blood, the blood constantly contained bacteria throughout the period of examination in each of the 8 cases, even the 7-hr. blood samples revealing numerous colonies upon incubation of only 1 drop of blood in broth and at least several colonies on plate. Accordingly, the concurrence of erythrocytes and bacteria in the 1-hr. and later urine in the 2 cases mentioned suggests that bleeding occurred in the bladder when puncture of the bladder was made twice to take samples and some of the bacteria in the blood stream transferred directly into the bladder.

Series 2: Experiments with an enterococcus. In 5 of 8 cases tested with an enterococcus, the urine remained sterile throughout the period ex- 
amined in each case.

In the remaining 3 cases (cases 6 to 8 ), the urine was positive for bacteria in broth culture in the 4-hr. sample of case 6, the 6-hr. sample of case 7 , and the 7-hr. sample of case 8 , all the other samples being sterile. At about the time of appearance of each positive urine, erythrocytes were detected in the urine and the benzidine test was positive, too (Table III).

\section{TAB LE III}

Changes by Injection of an Entercococcus

\begin{tabular}{|c|c|c|c|c|c|c|c|c|c|c|c|}
\hline \multirow{2}{*}{ No. } & & & \multirow{2}{*}{$\begin{array}{l}\text { Before } \\
\text { injection }\end{array}$} & \multicolumn{8}{|c|}{ Time (hrs.) after injection } \\
\hline & & & & 0.5 & 1 & 2 & 3 & 4 & 5 & 6 & 7 \\
\hline \multirow{5}{*}{96} & \multirow{2}{*}{$\stackrel{\stackrel{\Xi}{5}}{5}$} & in broth & - & - & - & - & - & - & - & - & + \\
\hline & & on plate & - & - & - . & - & - & - & - & - & 一 \\
\hline & \multicolumn{2}{|c|}{ Erythrocytes in urine } & - & - & - & - & + & + & + & + & $H$ \\
\hline & \multicolumn{2}{|c|}{ Benzidine test } & - & - & - & - & - & - & + & + & + \\
\hline & \multicolumn{2}{|c|}{ Albumin in urine } & - & - & - & - & - & - & - & - & - \\
\hline
\end{tabular}

As blood incubation tests for bacteria in the present series of experiments constantly yielded positive results as in series 1, even only one drop of the 7-hr. blood revealing bacteria on plate, the presence of bacteria in the 4-hr. or later urine samples of the 3 cases mentioned may be ascribed to the bleeding due to previous punctures of the bladder.

Further, it is to be noted that even in the above 3 cases (where bacteria were detected in the 4-hr. or later urines) the urines were always negative on plate. Thus, so far as the results of culture on plate are concerned, in each case of series 2 the urine remained constantly sterile throughout the period of examination.

Series 3: Experiments with $B$. proteus vulgaris. Of 8 cases tested, only 2 (cases 1 and 2) yielded the results that the urine was negative for bacteria both on plate and in broth throughout the period of examination. In case 3 , the urine had been sterile till 2 hours after injection, but was positive after 3 hours in broth and after 6 hours on plate. At about the time when the urine became positive for bacteria there was observed the first appearance of erythrocytes in the urine examined.

In the remaining 5 cases, the urine was positive in broth already in the first sample (taken $0.5-\mathrm{hr}$. after injection) and also on plate in the 2or 3-hr. and later samples. If some discrepancy in time is looked over, it may be said in these cases, too, that there was observed a concurrence of bacteria and erythrocytes in the urine; and, as erythrocytes increased in 
number, the urine samples became positive for bacteria on plate also, and for the benzidine and albumin tests, too (Table IV).

$$
\text { TABLE, IV }
$$

Changes by Injection of B. proteus vulgaris

\begin{tabular}{|c|c|c|c|c|c|c|c|c|c|c|c|}
\hline \multirow{2}{*}{ No. } & & & \multirow{2}{*}{$\begin{array}{c}\text { Before } \\
\text { injection }\end{array}$} & \multicolumn{8}{|c|}{ Time (hrs.) after injection } \\
\hline & & & & 0.5 & 1 & 2 & 3 & 4 & 5 & 6 & 7 \\
\hline \multirow{5}{*}{69} & \multirow{2}{*}{ 号泀 } & in broth & - & + & + & + & + & + & + & + & + \\
\hline & & on plate & - & - & - & + & + & + & + & + & + \\
\hline & \multicolumn{2}{|c|}{ Erythrocytes in urine } & - & \pm & \pm & $H$ & $H$ & H & $H$ & H & H \\
\hline & \multicolumn{2}{|c|}{ Benzidine test } & - & -- & - & + & + & + & + & + & + \\
\hline & \multicolumn{2}{|c|}{ Albumin in urine } & - & - & -- & -- & \pm & \pm & + & + & + \\
\hline
\end{tabular}

If solely the results of culture on plate are referred to in the presen $t$ series of experiments, it will be seen that the urine was sterile throughout the period of examination in 2 cases, and became positive after 2 hours in 1 case, after 3 hours in 3 cases, after 5 hours in case and after 6 hours in the remaining 1 case.

Series 4: Experiments with Mycobacterium 607. For the present series of experiments 10 rabbits were used. Tests of urine for bacteria were made by microscopic examination of the stained sediments of the urine and by cultivation, but the former method was found much inferior to the latter for the present purposes; the results will, therefore, be described here only of cultivation:

In 2 of the 10 cases, the urine remained free from both bacteria and erythrocytes throughout the period of examination.

In 3 cases, the urine had remained sterile for the first 3 hours, but became positive 4 or 5 hours after injection; the positive urines were found to be accompanied by erythrocytes (Table $\mathrm{V}$ ).

In the remaining 5 cases, the urine had become positive within 30 minutes ( 1 case), 1 hour ( 1 case) or 2 hours ( 3 cases); also in these cases the positiveness of the urine for bacteria was seen to be associated with the presence of erythrocytes or the positiveness of the benzidine test (Table VI).

Series 5: Experiments with avirulent $B$. coli. In 8 cases tested there was not a single case in which the urine remained sterile throughout the period of examination. In only 1 case the ruine had remained sterile in broth for the first 1 hour and on plate for the first 4 hours after injection; erythrocytes were detected in none of the positive urines. 
TABLE V

Changes by Injection of Mycobacterium 607

\begin{tabular}{|c|c|c|c|c|c|c|c|c|c|c|}
\hline \multirow{2}{*}{ No. } & & \multirow{2}{*}{$\begin{array}{l}\text { Before } \\
\text { injection }\end{array}$} & \multicolumn{8}{|c|}{ Time (hrs.) after injection } \\
\hline & & & 0.5 & 1 & 2 & 3 & 4 & 5 & 6 & 7 \\
\hline \multirow{4}{*}{39} & Urine culture & - & - & - & - & - & - & + & + & + \\
\hline & Erythrocytes in urine & - & - & - & - & \pm & - & \pm & + & + \\
\hline & Benzidine test & - & - & - & - & - & - & - & - & + \\
\hline & Albumin in urine & - & - & - & - & - & - & - & - & - \\
\hline
\end{tabular}

TABLE VI

Changes by Injection of Mycobacterium 607

\begin{tabular}{|c|c|c|c|c|c|c|c|c|c|c|}
\hline \multirow{2}{*}{ No. } & & \multirow{2}{*}{$\begin{array}{l}\text { Before } \\
\text { injection }\end{array}$} & \multicolumn{8}{|c|}{ Time (hrs.) after injection } \\
\hline & & & 0.5 & 1 & 2 & 3 & 4 & 5 & 6 & 7 \\
\hline \multirow{4}{*}{38} & Urine culture & - & - & - & + & + & + & + & + & + \\
\hline & Erpthrocytes in urine & - & - & - & + & $H$ & 州 & Hit & $H$ & H \\
\hline & Benzidine test & - & - & - & - & + & + & + & \pm & \pm \\
\hline & Albumin in urine & - & - & - & - & - & - & - & - & - \\
\hline
\end{tabular}

In the remaining 7 cases, all the broth culture tests yielded positive results already with the first samples (the 0.5-hr. urines); in 3 cases of them there was seen a general parallelism between the presence of bacteria and the appearance of erythrocytes in the urine, while in the remaining 4 cases erythrocytes were not demonstrated in some of the bacterium-positive urines, which findings are not easy to explain (Table VII).

\section{TABLE VII}

Changes by Injection of Avirulent B. coli

\begin{tabular}{|c|c|c|c|c|c|c|c|c|c|c|c|}
\hline \multirow{2}{*}{ No. } & & & \multirow{2}{*}{$\begin{array}{l}\text { Before } \\
\text { injection }\end{array}$} & \multicolumn{8}{|c|}{ Time (hrs.) after injection } \\
\hline & & & & 0.5 & 1 & 2 & 3 & 4 & 5 & 6 & 7 \\
\hline \multirow{5}{*}{7} & \multirow{2}{*}{ 岙总 } & in broth & - & + & + & + & + & + & + & + & + \\
\hline & & on plate & - & -- & - & + & - & - & + & + & + \\
\hline & \multicolumn{2}{|c|}{ Erythrocytes in urine } & - & - & - & - & - & - & -- & \pm & \pm \\
\hline & \multicolumn{2}{|c|}{ Benzidine test } & - & - & - & - & - & - & - & - & - \\
\hline & \multicolumn{2}{|c|}{ Albumin in urine } & - & - & -- & - & - & - & - & - & - \\
\hline
\end{tabular}


So far as the results of culture on plate are concerned, the urine became positive for bacteria within 1 hour in 1 case, 2 hours in 1, 3 hours in 1,4 hours in 2, 5 hours in 2, and 7 hours in 1 .

Series 6: Experiments with avirulent $B$. coli on rabbits whose bilateral ureters had been ligated before injection. In the experiments thus far described, rabbits were intravenously injected with varying kind of bacterial suspension and samples of the bladder urine were taken by puncture of the bladder. In some cases the urine was constantly sterile throughout the period of examination; in the other cases the urine was often found positive for bacteria, where it was generally found that the positiveness of samples for bacteria was seen in association with the presence of erythrocytes, with the exceptions of the cases with avirulent B. coli, B. proteus vulgaris, and Mycobacterium 607 , in which there were encountered bacterium positive but erythrocytenegative urine samples. To clarify the reason for the appearance of these exceptions, the following experiment was made: After preventing urine from flowing into the bladder by bilateral ligature of the ureters, a suspension of avirulent $B$. coli was injected intravenously; then, in order to see whether bacteria made their appearance in the urine that had deposited in the bladder before the ligature, 7 urine samples were taken by puncturing the bladder at intervals of 10 minutes during the period between 10 and 70 minutes after injection. With 5 rabbits tested it was found that bacteria made their appearance already in the first or second sample of the bladder urine; for example, the urine in case 4 (Table VIII) was negative for bacteria in the first sample, but became positive in broth in the second sample and on plate in the fourth (40-min.). In these positive urines erythrocytes were also detected and the benzidine test became positive later. These findings suggest that the appearance of bacteria in the urine was due to bleeding caused by puncture of the bladder.

\section{TABLE VIII*}

Changes by Injection of Avirulent B. coli

\begin{tabular}{|c|c|c|c|c|c|c|c|c|c|c|}
\hline \multirow{2}{*}{ No. } & & & \multirow{2}{*}{$\begin{array}{l}\text { Before } \\
\text { injection }\end{array}$} & \multicolumn{7}{|c|}{ Time (mins.) after injection } \\
\hline & & & & 10 & 20 & 30 & 40 & 50 & 60 & 70 \\
\hline \multirow{5}{*}{78} & \multirow{2}{*}{ 象总 } & in broth & - & - & + & + & + & + & + & + \\
\hline & & on plate & - & - & - & - & + & - & + & + \\
\hline & \multicolumn{2}{|c|}{ Erythrocytes in urine } & - & - & \pm & + & + & + & + & + \\
\hline & \multicolumn{2}{|c|}{ Benzidine test } & -- & -- & - & -- & \pm & + & + & + \\
\hline & \multicolumn{2}{|c|}{ Albumin in urine } & - & - & - & - & - & - & - & - \\
\hline
\end{tabular}

* Case 4, with bilateral ureters ligated. 
In case 2 (Table IX), on the other hand, the urine was positive in broth already in the first sample and became positive also on plate in the 30 -min. sample, while it was not until the 60 - or 70 -min. sample was examined that the presence of erythrocytes was clearly demonstrated.

\section{TABLE IX*}

Changes by Injection of Avirulent B. coli

\begin{tabular}{|c|c|c|c|c|c|c|c|c|c|c|}
\hline \multirow{2}{*}{ No. } & & & \multirow{2}{*}{$\begin{array}{c}\text { Before } \\
\text { injection }\end{array}$} & \multicolumn{7}{|c|}{ Time (mins.) after injection } \\
\hline & & & & 10 & 20 & 30 & 40 & 50 & 60 & 70 \\
\hline \multirow{5}{*}{79} & \multirow{2}{*}{ 导总 } & in broth & - & + & + & + & + & + & + & + \\
\hline & & on plate & - & - & - & + & + & - & + & + \\
\hline & \multicolumn{2}{|c|}{ Erythrocytes in urine } & - & - & - & - & -- & - & $H$ & H \\
\hline & \multicolumn{2}{|c|}{ Benzidine test } & - & - & - & - & - & - & + & + \\
\hline & \multicolumn{2}{|c|}{ Albumin in urine } & - & -- & -- & - & -- & - & - & - \\
\hline
\end{tabular}

Further, it is to be noted that the time of appearance of bacteria on plate in these 5 cases was earlier than in the previous experiments with non-ligature of the ureters, being within 30 minutes in 3 cases, 40 minutes in 1 , and 50 minutes in 1, which makes a marked contrast with the time of appearance in the previous experiments: after 4 hours or later in more than half the cases and within 2 hours in only 2 cases out of the 8 . This earlier appearance of bacterium-positiveness on plate in the present series of experiments with the same bacterial suspension as in the previous one might conceivably be due to heavier bleeding by frequent puncture of the bladder within a short period of time. The appearance of bacteria in the bladder urine in the present series of experiments, where the ureters had been ligated bilaterally, might not be explained in other way than that bacteria in the blood stream transferred directly into the bladder on account of bleeding due to the bladder puncture. The discrepancy in the time of appearance in the urine between bacteria and erythrocytes may be explained as follows: At the time of previous punctures there occurred bleeding, but it was only slight; and a large majority of erythrocytes sank deep beyond the reach of the needle of a syringe, thus escaping being sucked up together with the bladder urine. A similar discrepancy as seen in series 5 of experiments may be explained in the same manner.

\section{Discussion}

In my series of experiments with $B$. subtilis (series 1 ) and with an 
enterococcus (series 2), 6 and 5 out of the 8 cases yielded the results showing the incapability of bacteria to pass through the normal kidney in that the urine in each case was found upon incubation to remain constantly sterile during the period till 7 hours after the intravenous injection of bacteria. In the remaining 2 cases in series 1 and 3 in series 2 , the urine was at first sterile but later became positive, although upon culture on plate in thest 3 cases in series 2, the urines were constantly free from bacteria throughout the period of examination.

With the positive urines in series 1 and 2 there were obtained those findings, such as the appearance of erythrocytes and positive benzidine tests, which were suggestive of bleeding in the bladder due to the previous punctures for taking urine samples. In addition, the blood constantly contained bacteria throughout the period of examination in all cases, even the plate culture, as well as the broth culture, of only one drop of the 7-hr. blood sample revealing not less than several colonies. From these facts the occurrence of bacteria in the bladder urine may be taken due to contamination with bacterium-containing blood flown out at the times of previous bladder punctures.

In series 3 of experiments with $B$. protens vulgaris, the urine was constantly sterile throughout the whole period in 2 out of the 8 cases. In other 1 case, the urine became positive in broth 3 hours after injection and also on plate after 6 hours, which may also be due to the bleeding. In the remaining 5 cases, the urine was positive in broth already at the first test after injection; it became positive on plate, too, in the 2-, 3-, or 5-hr. sample. Erythrocytes were detected in these positive urines, and their time of the first appearance agreed with that of bacteria on plate. The appearance of bacteria in broth, however, was seen earlier than that of erythrocytes.

In series 4 of experiments with Mycobacterium 607, 2 out of the 10 cases produced sterile urine throughout the. whole period, and 3 cases yielded positive results first after 4 or 5 hours; thus, it will be noted that these 5 cases had produced sterile urine till 3 hours after injection. In the remaining 5 cases. the urine became positive 1 or 2 hours after injection. In this series of experiments the time of appearance of bacteria was found to agree well with that of erythrocytes.

In series 5 of experiments with avirulent $B$. coli, there was observed only 1 case in which the urine had remained sterile in broth for the first 1 hour. In the remaining 7 cases, the urine was constantly positive for bacteria in broth throughout the period of examination, while it became positive on plate 1 to 7 hours after injection; bacteria and erythrocytes did not always appear simultaneously in the urine, the bacterium-positiveness 
appearing in advance frequently.

In series 6 of experiments with avirulent $B$. coli, in which the ureters had been ligated bilaterally, before injection, to prevent the renal urine from flowing into the bladder, and urine samples were taken at intervals of 10 minutes during the period of 70 minutes following injection, the urine was positive for bacteria. This positiveness seems to have been due to bleeding at the time of puncture. To the discrepancy in the time of appearance as sometimes observed between bacteria and erythrocytes the following explanation has been given: There occurred a slight bleeding at the time of previous punctures, but a large majority of erythrocytes sank deep beyond the reach of the needle of a syringe and escaped being mixed into the urine sample. In addition, it is to be noted that the earlier appearance of bacteria on plate in this series of experiments than in the other is suggestive of the dependence of the appearance of bacteria in the urine upon the frequency of punctures.

In performing precise experiments on the passage of bacteria through the normal kidney, the most important thing is to obtain urine samples which are free from blood as aseptically as possible. Among various methods devised for obtaining urine samples, the method in which samples are obtained by puncturing the exposed bladder wolud be the best, as pointed out by Helmholz and others, ${ }^{101}$ Okubo, ${ }^{71}$ and other workers, though it is not without defects. In the present study, too, preliminary tests were made for comparing different methods, and it was found that more accurate results were to be obtained with urin samples taken by direct puncture of the exposed bladder than with samples taken by means of a metal catheter or the Nélaton's catheter, or by puncture through the abdominal wall.

A large number of investigations have been reported as to this problem; and two opposite conclusions have been published: one, in favor of the view of the passage, and the other, against this view. This difference may be due to differences in the amount of intravenous injection of bacteria, in the method for obtaining urine samples, and in other points. Closer inspection of experimental results obtained by various authors, on the other hand, tells us that quite different conclusions may be derived by different interpretations of similar experimental results.

There have been published in our country several papers in support of the view of the passage of bacteria through the normal kidney, such as a paper in which the appearance of bacteria has been demonstrated in the bladder urine already 5 minutes after injection of bacteria into the blood stream (Okubo ${ }^{7}$ ) and Sasaki $\left.{ }^{11}\right)$, a paper in which bacteria have been demonstrated in some samples of the bladder urine taken by means of the Nelaton's catheter after some time following intravenous injection of bac- 
teria (Tsutsui $\left.{ }^{4}\right)$, a paper in which there were no direct evidences as to the presence of bacteria in the bladder urine, but conclusions in favor of the view of passage have been reached from histologic examination revealing bacteria in the renal tubules (Tsutsui $\left.{ }^{4}\right)$ and $A \mathrm{Abe}^{81}$ ), and a paper in which bacteria have been demonstrated in the bladder urine with increase in number of bacteria in the blood stream (Orikasa $\left.{ }^{6}\right)$ ).

In the present study, where suspensions of five species of well-growing, non-pathogenic bacteria were intravenously injected in great amounts, the bladder urine would often remain constantly sterile in broth as well as on plate even 7 hours after injection when experimental techniques were successful, which results deny the passage of bacteria through the kidney.

It was also often the case with the present study that the bladder urine that had been sterile at first became positive for bacteria 3 to 4 hours after injection, simultaneously with the appearance of erythrocytes. According to Dyke, ${ }^{12)}$ those bacteria which make their appearance in the bladder urine first after 3 to 4 hours cannot be regarded as the secretion or excretion of the kidney. From the facts that the excretion from the kidney of pigments, such as phenolsulfonphthalein or methylene blue, or other foreign bodies such as a contrast medium for intravenous pyelography reaches its maximum 30 minutes after the intravenous injection, becoming very small in amount after the intravenous injection, becoming very small in amount after 2 hours, I approve Dyke's opinion. And indeed in the present study it has been demonstrated that the appearance of bacterium-positive bladder urines first after 3 or 4 hours was due to secondary bleeding caused by puncturing the bladder.

Further, it was found in some cases that the appearance of bacteria was in advance of that of erythrocytes. Ane indeed some cases of bilateral ligature of the ureters were encountered in which there occurred bleeding but erythrocytes were not mixed in the urine sample, and they appeared first in later urine samples.

The 5 species of bacteria tested yielded different results; $B$. coli, the most actively multiplying and best growing one among them, was found to appear in the bladder urine earlier than other bacteria. As the puncture of the bladder was made before bacterial injection in this study to confirm the sterility of the bladder urine before injection, there might possibly occur some cases in which this very well growing $B$. coli enter the bladder urine upon bleeding due to puncture aud make later urine samples positive.

As to experiments on the passage of bacteria through the kidney different results have been reported on account of the difficulty encountered in taking the bladder urine free from blood aseptically and periodically. Even if similar results have been obtained, different conclusions may conceivably 
be reached in some cases owing to differences in interpretation of the results. The results obtained in the present study also contain both those results which can deny the passage of bacteria completely and those which cannot deny it with certainty. The latter doubtful results, however, were found to have been due to the bleeding caused by puncture of the bladder, and therefore these results are against the view that bacteria can pass through the normal kidney.

\section{SUMMARY}

With a view to ascertaining whether bacteria can pass through the normal kidney, suspensions of 5 species of nonpathogenic bacteria were abundantly injected into the ear veins of rabbits, samples of the bladder urine were taken by direct puncture of the previously exposed bladder, and the urine samples were incubated and tested for bacteria, with the results to be summarized as follows :

1. With $B$. subtilis and an enterococcus, the bladder urine constantly remained sterile, in relatively many cases, throughout the period of examination from 0.5 to 7 hours after injection ( 8 samples). Similar results were obtained in a few cases with other species of bacteria. These results are in support of the view denying the passage of bacteria through the normal kidney.

2. In some cases, the bladder urine was sterile at first but became positive 3 or 4 hours after injection. In the positive urine samples concurrent appearance of erythrocytes was demonstrated. From the common knowledge as to the excretion by the normal kidney of pigment or some other foreign body, those bacteria that appeared in the bladder urine first after 3 or 4 hours cannot be regarded to have been excreted by the kidney, but may possibly be what had transferred from the blood stream into the bladder urine on account of bleeding due to puncture of the bladder.

3. With avirulent $B$. coli, which is the most actively multiplying and best growing species of the bacteria tested, it was often the case that the appearance of bacteria in the urine was in advance of that of erythrocytes. In experiments of bilateral ligature of the ureters (with avirulent $B$. coli) also similar cases were observed when bacteria in the blood stream transferred directly to the bladder urine.

4. These results may be taken to be in favor of the view denying the passage of bacteria through the normal kidney.

\section{References}

1) Helmholz \& Millikin, Amer. J. Dis. Child., 1925, 29, 497.

2) Tschiknawerow, Zschr. Hyg., 1933, 114, 610. 
3) Book, Amer. J. Path., 1933, 9, 569.

4) Tsutsui, Fukuoka Ikadaigaku Zasshi (Jap.), 1927, 20,125.

5) Nishikawa, Manshu Igaku Zasshi (Jap.), 1934, 21, 69. Nishikawa, ibid., 1936, 24, 301.

6) Orikasa, Nihon Hinyokika Gakkai Zasshi (Jap.), 1936, 25, 631.

7) Okubo, Hokkaido Igaku Zasshi (Jap.), 1941, 19, 1062.

8) Abe, Tohoku J. Exp. Med., 1949, 50, 207.

9) Monma, ibid., in press.

10) Helmholz, Ruth \& Field, Amer. J. Dis. Child., 1925, 29, 641.

11) Sasaki, Hifuka Kiyo (Jap.), 1929, 14, 487.

12) Dyke, J. Path. Bact., 1923, 26, 164. 